\title{
Ivar Ugi: An exceptional scientist and human being. In Memorial Ivar Ugi
}

Ivar Ugi, a great scientist and exceptional human being recently left us. He died after a long and painful disease at the 27 September 2005. In memoriam Ivar Ugi this special issue of Heterocyles is edited with many contributions of his scientific friends and colleagues.

He was born 1930 in Kuresare on the island Sareemma in Estonia. In 1941 the family Ugi left Estonia and moved to Dillingen an der Donau in Bavaria/Germany. There he went to high school. He studied mathematics and chemistry at the University of Tübingen. At the Ludwig Maximilian Universität in München he performed his $\mathrm{PhD}$ under the guidance of Prof. Rolf Huisgen. At the same university he performed his Habilitation "Isonitrile und Pentazole”. In 1962 he become married with his wife Helga and his son Ian was born. In the same year the family Ugi went to Leverkusen, where he joints the central research laboratory of the Bayer AG. Soon he became promoted to the "Research Director" and "Chairman of Bayer's Basic Research Committee”. During his time at Bayer Ivar Ugi and Otto Bayer became very good friends. However he realized that his managerial positions at Bayer mostly involved organisational work and prevented him from following his scientific ideas in the lab. Therefore, he was very lucky when he got a full chair for chemistry offered at the University of Southern California (USC) in the US. He stayed there form 1969 to 1971 and partially till 1973. In 1971 he moved back to Munich/Germany where he became offered the prestigious "Hans Fischer" chair at the Technische Universität München. In the line of his famous predecessors Hans Fischer, Stephan Goldschmidt, Emil Fischer and Heinrich Wieland, Ivar Ugi clearly was a worthy successor. He stayed there till his retirement in 1999. Ivar Ugi's honors and awards are summarized in Table 1. When the Ugi family left Estonia in 1941 Ivar Ugi lost his mother tongue as time went by. However he learned again fluently to speak Estonian after he regularly visited Estonia after the fall down of the Iron Curtain. Moreover he was fluent in speaking Estonian, German, English, Russian and Polish.

\section{Awards, Honors}

\author{
- 1964 Research Prize of the Academy of Sciences of Göttingen (“Theoretical \\ Stereochemistry") \\ - 1987 Member of the Swedish Royal Society of Science \\ - 1987 Honour Member of the New York Academy of Science \\ - $\quad 1988$ Philip Morris Research Prize ("Dugundji-Ugi model of computer chemistry") \\ - 1990 Member of the Estonian Academy of Sciences \\ - 1992 Emil Fischer Award of the German Chemical Society ("MCR") \\ - 1995 Dugundji medal ("Mathematical Approaches to Chemistry") \\ - 1999 Max Bergmann Medal of the MBK
}

Table 1. Ivar Ugis Honors and Awards.

Ivar Ugi became interested in Chemistry as a youngster in Germany when explosives where abundant and available during the Second World War. He collected lost bombs, extracted the explosives and experimented with them. However, sometimes he also noticed the chemical similarity between the antiheadache compound Phenazetin and the artificial sweetener Dulzin (Scheme 1). He bought all available Phenazetin form the surrounding pharmacies he could get hands on. In mothers kitchen he then converted 
Phenazetin in Dulzin. Because sugar and sweeteners where very rarely available in the Germany of the second world war he sold his synthesized Dulzin gaining high prizes. This extra income secured the food supply of the Ugi family in this time. Thus, sometimes even honey was affordable to them.

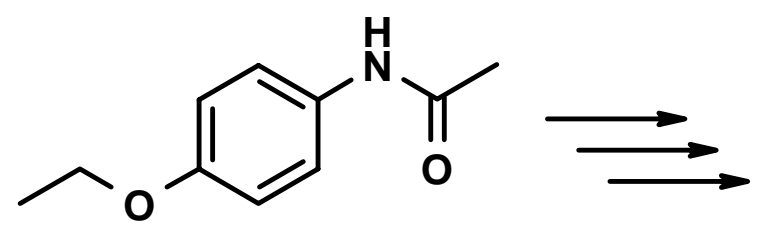

Phenazetin

"anti-headache"<smiles>CCOc1ccc(NC(N)=O)cc1</smiles>

Dulzin

"artificial sweetener"

Scheme 1. Phenazetin and its conversion into Dulzin in Ivars mother "kitchen laboratory".

Ivar Ugi was a very exceptional person and scientist. He had his own and strong sense for humor (Figure 1). As a human person he was very generous and open minded to other ideas and habits. He used to have many friends from all over the world.
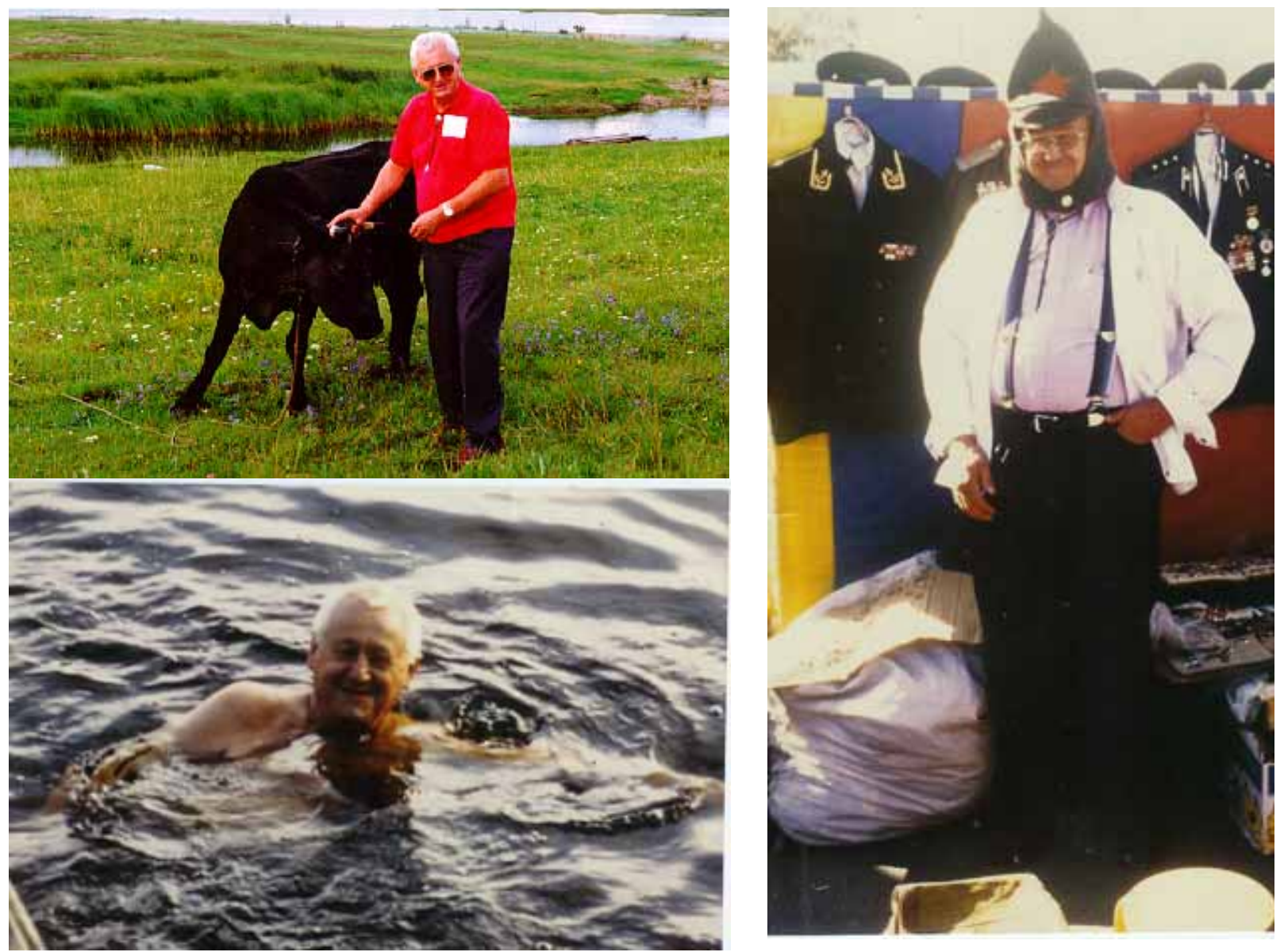

Figure 1. Ivar had his own great and unique sense of humour. Left: Ivar during a bull-fight in Estonia, below: Ivar taking a bath in the Baltic Sea, right: Ivar trying an old Russian tank driver cap. (Photographs reproduced with the kind permission of his wife Helga Ugi).

Ivar Ugi's research was devoted to fundamental questions in Chemistry by utilizing his strong mathematic and chemistry background, successfully marrying Chemistry and Mathematics. His research 
had an immense impact in an extensive variety of scientific fields, including applied sciences. These range from investigations on the formation and synthesis of pentazoles, isocyanides, the ever growing field of multi component reactions with important applications in combinatorial chemistry and drug discovery, phosphorous chemistry, stereochemistry and computational chemistry ("the logic of chemistry"). He published more than 300 scientific papers and several books. His major scientific achievements are summarised in the following paragraphs, but by no means this intends to be comprehensive summary (see however Ivar Ugis publication list!).

\title{
Pentazoles, the way to isocyanides, the discovery of the Ugi four component condensation and the start of combinatorial chemistry.
}

Pentazoles constitute a great challenge. Their existence was postulated already in the $19^{\text {th }}$ century. Many famous chemists, e.g. Hantzsch (1903), Dimroth (1910), Lifschitz (1915), Curtius (1915), Wiberg and others tried to synthesize pentazoles by different means, without success. However Ugi and Huisgen synthesized the first time pentazoles by reacting phenyl diazo compounds with azide salts at low temperatures. Moreover by performing elegant kinetic measurements and ${ }^{15} \mathrm{~N}$ labelling studies they were able to prove their formation, existence and decay (Figure 2). Pentazoles are so labile and explosive that only recently the X-rays structure of phenyl pentazole and some other pentazoles could be obtained at $100^{\circ} \mathrm{C}^{1}$

\section{ivar Ugi, Hans Perlinger*) und Liselotte Beitringer}

Pentazole, III

\section{Kristallisierte Aryl-pentazole}

Aus dem Institut für Organische Chemie der Universitit München

(Eingegangen am 14. Juli 1958)

\begin{abstract}
Aus Aryl-diazoniumehloriden und Alkaliazid werden kristallisierte Arylpentazole dargestellt. Die UV-Absorptionsspektren zeigen, daB das PentazolSystem als Substituent stark elektronenanziehend wirkt. Die 7erfallswirme von $[p$-Ẍthoxy-phenyl]-pentazol wird zu $5.4+0.2 \mathrm{keal} / \mathrm{Mol}$ gefunden. Mit zunehmender Polarität des L.ösungsmittels sinkt die Zerfatls- $R G$ von gelïstem Phenyl-pentazol.
\end{abstract}

Figure 2. First synthesis of crystalline pentazoles described in Chemische Berichte in 1958.

Isocyanides were basic materials for Ugi's early pentazole research to obtain reference tetrazole materials, to study the difference between these isoelectronic heterocyclic systemes. A very efficient and fruitful synthetic access to the substituted tetrazoles is the 1910 discovery Oliveri-Mandalá and Alagna-synthesis employing isocyanides and $\mathrm{HN}_{3}$. However Ugi realized that time known and "classical” approaches towards isocyanides, the $19^{\text {th }}$ century Hoffman carbylamine, Gautier and Liecke methods, where by no means good methods for an efficient and general access towards these compounds. Therefore he thought about alternative routes and came up with the 2 step sequence of amine formylation and subsequent dehydration. Interestingly already 1867 Gautier tried this rather "obvious" route for the synthesis of isocyanides. However missing the addition of a base to capture the formed acid byproduct of the dehydrating agent Gautier could never obtain any isocyanide by this route, due to the acid labile character of isocyanides. Despite many elaborated ways to access isocyanides, Ugi's method comprise today's standard synthetic route to this important class of organic molecules (Scheme 2). Today thousands of isocyanides are prepared by this method and are commercially available. 


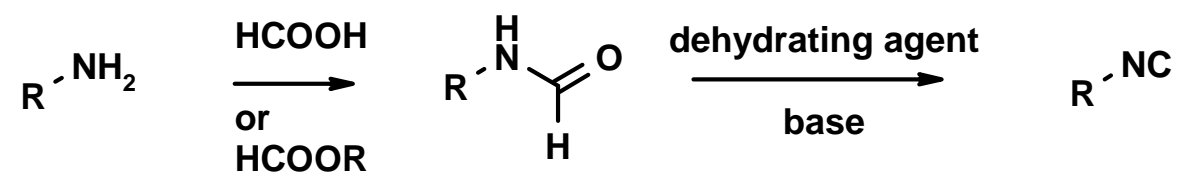

dehydrating agents: $\mathrm{POCl}_{3}$, TosCl,<smiles>O=C(Cl)Cl</smiles><smiles>O=C(Cl)OC(Cl)(Cl)Cl</smiles><smiles>O=C(OC(Cl)(Cl)Cl)OC(Cl)(Cl)Cl</smiles>

base: $\mathrm{NEt}_{3}$, Hünig, pyridine

Scheme 2: The dehydration route to form isocyanides form $\mathrm{N}$-formamides, today's standard method of isocyanide production.

Investigating the properties and reactivity of the that time hardly broadly accessible isocyanides lead to the discovery of the fare leading four component condensation which eventually started the totally new area of multi component reaction (MCR) chemistry (Figure 3). Shortly before Christmas 1957 Ugi ordered his $\mathrm{PhD}$ student Steinbrückner to put the reaction between the four components isocyanide, primary amine, aldehyde and a carboxylic acid. It happened that Steinbrückner - already in Christmas mood - put the four components grudgingly together. That time a usual scale for a chemical reaction was at least $100 \mathrm{mmol}$. As most of the Chemical Institutes that time, the one of the Ludwig Maximilians Universität in Munich located in the Karlstrasse didn't have central heating. Therefore students worked with coat at the benches in winter times. Being distracted by other means Steinbrückner didn't control the reaction carefully and it soon went through and the reaction was spilled over his new coat. Steinbrückner now was very angry about Ugi blaming him for the loose of his expensive coat. In the new year, however, Ugi told Steinbrückner to carefully repeat the reaction. Thus in between only 6 month the essential variants of the Ugi multi component reactions where discovered, including $\alpha$-aminoacylamides, $\beta$ lactames, hydantoin-4-imides, 2-thiohydantoin-4-imides, $\alpha$-hydrazinocarbonamides, urethanes, selenoamides, thioamides, amides, diacylamides and amidines of $\alpha$-amino acids, as well as tetrazoles. In the most general definition the Ugi reaction comprise the reaction of a Schiff base or an enamine, an isocyanide and an acid, followed by a suitable rearrangement.

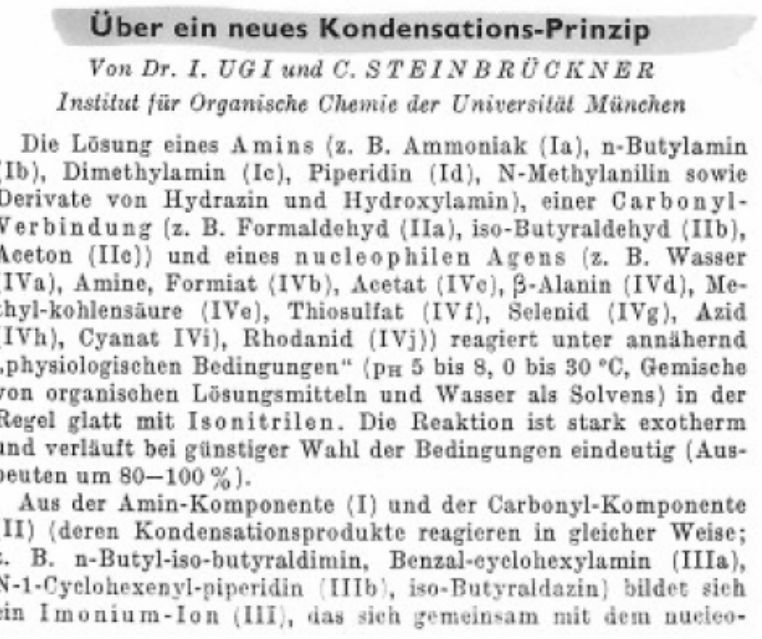

Angew. Chem. / 72. Jahrg. $1960 /$ Nr. $7 / 8$ philen Partner (IV) an das Isonitril (V) anlagert unter Bildung einer Imino-acyl-Verbindung (VI), welehe sieh je naeh Konstitution unter Protonenverschiebung, Acyl-Wanderung oder Ringsehluß in stabile Produkte umwandelt.

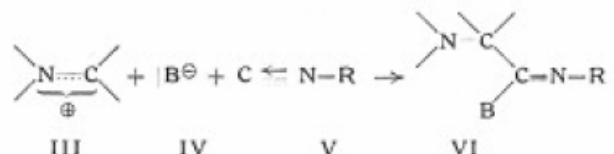

So entsteht aus Id, IIa, IVa und Cyelohexyl-isocyanid (Va, das wegen seiner leichten Zugãngliehlseit meist verwendet wurde) bei $0^{\circ} \mathrm{C}$ in waBrigem Methanol in 5 min mit $90 \%$ Ausb. Piperidinoessigsăure-N-cyclohexyl-amid ( $\mathrm{Fp} 73-74^{\circ} \mathrm{C}$ ). Weitere Beispiele: $\mathrm{N}$-n-Butyl-imino-diessigsaure- $\mathrm{N}^{\prime}, \mathrm{N}^{\prime \prime}$-dieyclohexyl-diamid $(84 \%$ d. Th. aus Ib, IIa, IVa und $\mathrm{Va}$; Fp $120,5-121^{\circ} \mathrm{C}$ ); N-Formyl-valin$\mathrm{N}^{\prime}=$ eyelohexyl-amid $(54 \%$ d.Th. aus Ia, IIb, IVb und $\mathrm{Va} ; \mathrm{FP}$ $\mathrm{N}^{\prime}$-eyclohexyl-amid $(54 \%$ d. Th. aus Ia, IIb, IVb und Va; Fp
$\left.199-200^{\circ} \mathrm{C}\right) ; \mathrm{N}$-Acetyl-N-eyclohexyl-amino-phenyl-essigsiure- $\mathrm{N}^{\prime}$ eyclohexyl-amid $(79 \%$ d. Th. aus IIIa, IVe und Va); N-(2-Methyl1-N'-eyclohexyl-earbonamido-1-propyl)-3-propiolactam $(80 \% \mathrm{~d}$. Th. aus IIb, IVd und Va; Fp 99-101 C); N,N-Dimethyl-amino-

Figure 3: The ground braking paper on the discovery of a new condensation principle in Angewandte Chemie 1960. 
Ivar Ugi soon realized the immense practical advantages of his reaction. Due to its one-pot character MCRs are very easy to perform. In contrary to the classical assembly line of complex organic molecules (multi step sequential preparations) with many necessary standard operations including reaction set up, reaction observation, work up, purification and analysis, these operations have to be performed only once in the case of MCRs. Multicomponent processes are at a premium for the achievement of high levels of brevity and diversity, as they allow more than two simple and flexible building blocks to be combined in practical, time-saving one-pot operations. Due to their inherent simple experimental procedures and their one-pot character, they are perfectly suited for the nowadays important automated synthesis.

In 1958 Ugi presented his experimental results of this amazingly new reaction at a seminar in Darmstadt at the pharmaceutical company Merck and shortly later at the DuPont Central Research and Development Experimental Station, Wilmington, Delaware. Later during an official meeting of the German Chemical Society he presented his work in Heidelberg to his colleagues as well, but most of them didn't believe the results in the beginning. An early combinatorial and commercial application of the Ugi reaction is the one-pot synthesis of the local aesthetic Xylocain ${ }^{\circledR}$ and its derivatives by Ugi (Scheme 3).<smiles>[CH2-][CH2+]OCCCCNCC</smiles><smiles>Cc1cccc(C)c1NC(=O)CN(CC(=O)O)CC(=O)O</smiles><smiles>CCCCN1CCCCC1C(=O)Nc1c(C)cccc1Br</smiles><smiles>Cc1ccccc1NC(=O)C(C)N1CCCC1</smiles><smiles>CCCNC(C)C(=O)Nc1ccccc1C</smiles><smiles>Cc1cccc(C)c1NC(=O)CN1CCCC1</smiles><smiles>CCCNC(C)(C)C(=O)Nc1ccccc1C</smiles><smiles>CCCNCC(=O)Nc1c(C)cccc1Cl</smiles><smiles>CCN(CC)CC(=O)Nc1c(C)cccc1C(=O)O</smiles><smiles>CCN(CC)CC(=O)Nc1c(C)cc(C)cc1C</smiles><smiles>CCCNC(C)C(=O)Nc1c(C)csc1C(C)=O</smiles><smiles>Cc1cccc(C)c1NC(=O)C1CCCCN1C</smiles><smiles>Cc1cccc(C)c1NC(=O)C(C)N</smiles>

Scheme 3. The three component reaction of formaldehyde, piperidine and 2,6-dimethylphenylisocyanide yields in one pot Astra's local anaesthetic Xylocain ${ }^{\circledR}$. Moreover many other derivatives can be easily synthesized by this 3-CR in a combinatorial fashion.

Nowadays Ugi's MCRs comprise most of the known isocyanide-based multi component reactions. They are very popular to generate biased or general libraries of small molecules for screening purposes in agro as well as in pharmaceutical industries. Hundreds of different scaffolds have been reported in the chemical literature to be accessible by Ugi-type MCRs and eventually follow-on reactions. Taking into account the easiness of reaction performance and the broad availability of the starting materials as well as 
the reactions functional group tolerability MCR pave the way to a very large chemical space $\left(>10^{20}\right)$. It was Ivar Ugi in 1961 who foresaw the usefulness of isocyanide-based multicomponent reactions for the synthesis of very many compounds, nowadays called chemical libraries: "Since in this condensation reaction four components react with each other, the number of possible products is quite high. Already the use of ten of each component leads to $10^{4}$ combinations”. Clearly Ivar Ugi with his MCR chemistry heralded the age of combinatorial chemistry, 30 years before it became of use in the context of the many new targets discovered through the Human Genome Project and the interrelated High Throughput Era.

\section{Ugi's early entry into the field of SPS}

An important theme of today's combinatorial chemistry is solid phase synthesis (SPS), due to its assumed advantages of higher conversions using excess of reagents, cleaner reactions and easier product isolation and purification. Already in the late $1980^{\text {th }}$ Ugi and his group developed therefore resin bound isocyanides and investigated its properties as well as application in solid phase Ugi MCRs (Scheme 4), again years before the chemical community became interested in SPS.

\section{loading \\ $(\mathrm{mmol} / \mathrm{g})$}

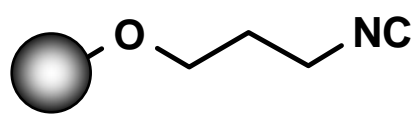

$0^{0} x^{N C}$<smiles>CN(CCOC(=O)CCCCC[N+]#N)c1ccccc1</smiles><smiles>N#Cc1ccc(CCNc2ccccc2)cc1</smiles>

1.0

1.9

2.8

\section{3}

Scheme 4: Examples of the first resin bound isocyanides useful in SPS described by Ugi in 1978.

In his late active years Ugi and his group became actively involved into the basics of combinatorial chemistry. They described the efficient chemical access to novel small molecular weight scaffolds and its libraries using MCR chemistry, e.g. $\alpha$-aminoacid based imino dicarboxylic acid derivatives or benzodiazepines. In another example they described the synthesis and deconvolution of the first MCRbased HIV protease inhibitors based on mixture-based combinatorial chemistry. Today the usefulness of MCR-based scaffolds to discover biologically active compounds has been extensively exemplified in the patent and chemical literature. Hits and leads covering the whole spectrum of pharmaceutical molecular targets, e.g. kinases, proteases, protein-protein interactions, DNA interacting targets and GPCRs have been discovered and developed at multiple pharmaceutical companies.

Hardly a field in organic chemistry has evolved faster over only a couple of years than multicomponent reactions (Figure 4). 


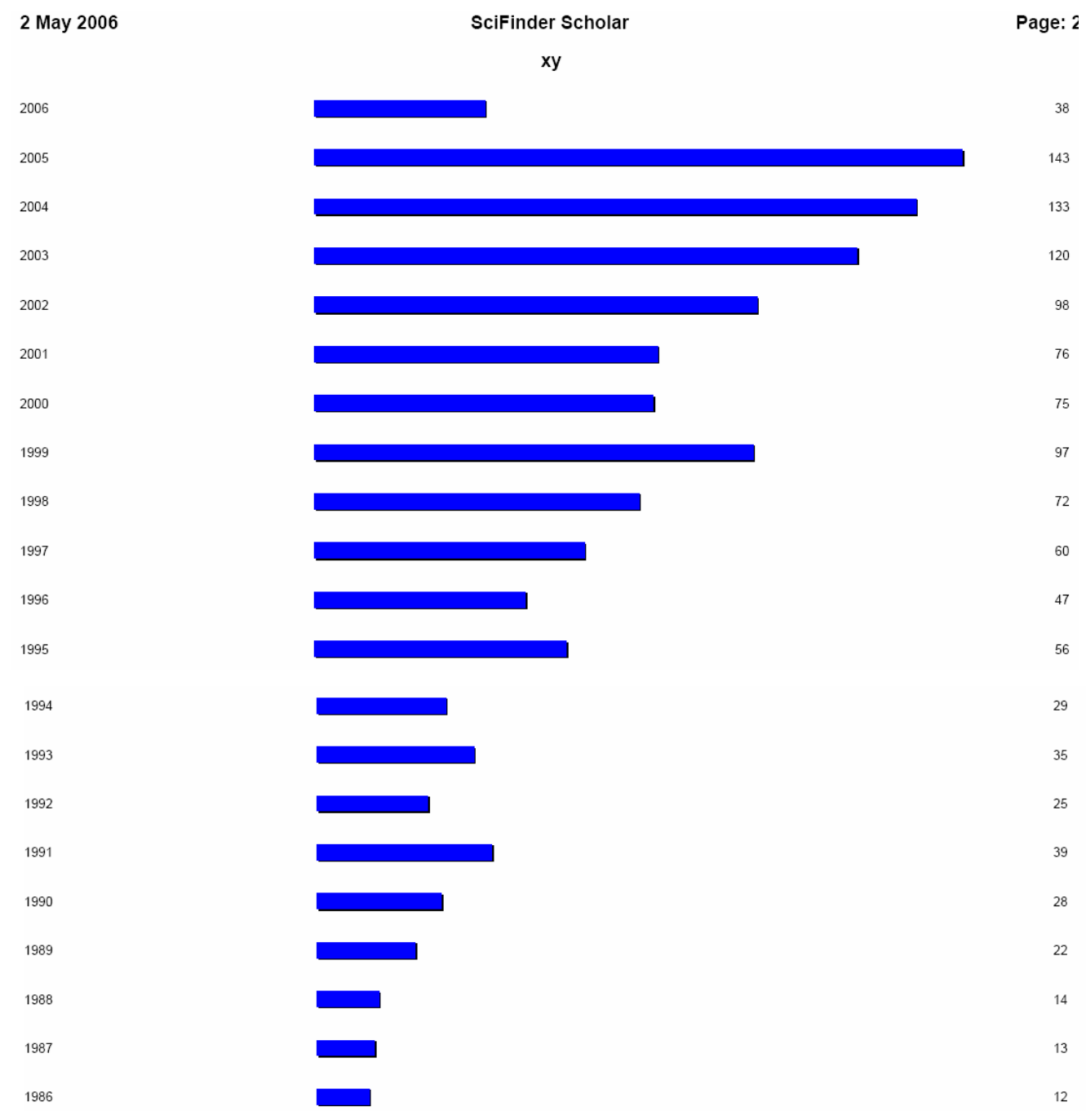

Figure 4: As to a recently performed SCI investigation, the field of multi component reactions is exponentially growing.

\section{The mathematical logic of Chemistry}

Ivar Ugi studied Mathematics and Chemistry in parallel. From this steams his high interest in the formalisation of Chemistry starting in the early $1960^{\text {th }}$, certainly an avantgardistic topic of chemical research that time. Together with the mathematician Ernst Ruch, Ivar Ugi developed the theoretical fundamentals of stereochemistry. As a "byproduct" he introduced a descriptor model for molecules with several stereocenters, the pn model (Scheme 5). This model was introduced in 1965, at a time when most of the organic chemists where hardly interested in the topic of stereochemistry. Interestingly Seebach and Prelog published a very similar model 10 years later however using a different nomenclature, the todays accepted $u l l k$ description. $^{2}$ 


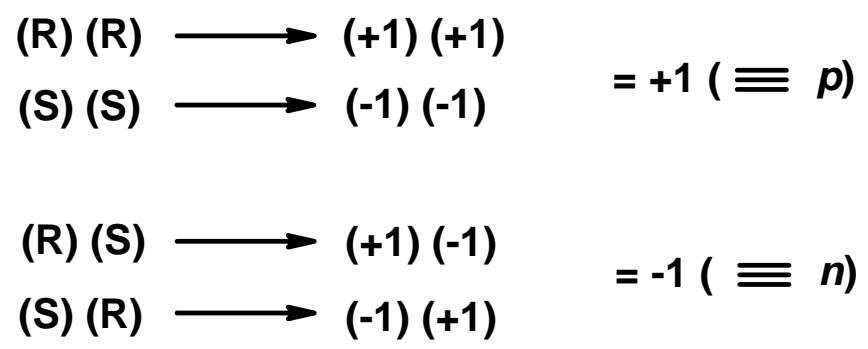

Scheme 5: Ugi's nomenclature describing the relative stereochemistry in molecules. In relation to mathematics, molecules obtain the prefix $\mathbf{p}$ for positive or $\mathbf{n}$ for negative if the formal product of the absolute stereocenters equals 1 or -1 .

Together with the world-class topologist and mathematician Jim Dugandji, Ivar Ugi developed a formalism later called Ugi-Dugandji model. Herein reactions are treated as ensembles of molecules that can be treated in analogy to isomerism. This constitutes a mathematic formalism which can be used in the prediction of synthetic pathways and the synthetic progress as measure by the "chemical distance". Programs based on this formalism differ form other software considerably in that they are not based on "rules”. However all possible synthesis routes can be investigated exhaustively.<smiles></smiles><smiles>CCC([O-])[O-]</smiles>

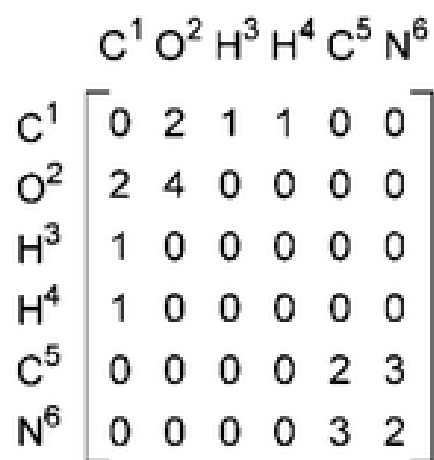

be-matrix $B$

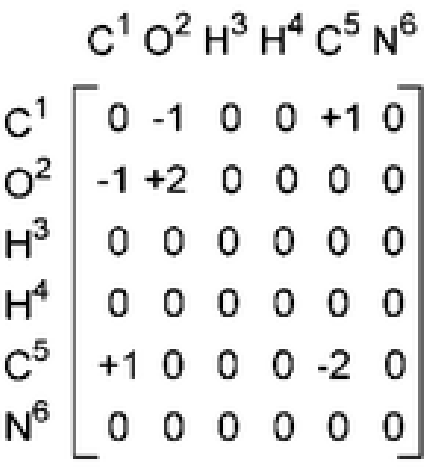

r-matrix R

\begin{tabular}{|c|c|c|c|c|c|c|}
\hline \multicolumn{7}{|c|}{$\mathrm{C}^{1} \mathrm{O}^{2} \mathrm{H}^{3} \mathrm{H}^{4} \mathrm{C}^{5}$} \\
\hline$C^{1}$ & 0 & 1 & 1 & 1 & & 0 \\
\hline $\mathrm{O}^{2}$ & 1 & 6 & 0 & 0 & 0 & 0 \\
\hline 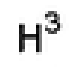 & 1 & 0 & 0 & 0 & 0 & 0 \\
\hline 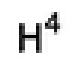 & & 0 & 0 & 0 & 0 & 0 \\
\hline & 1 & 0 & 0 & 0 & 0 & 3 \\
\hline & 0 & 0 & 0 & 0 & & \\
\hline
\end{tabular}

be-matrix $\mathrm{E}$

Scheme 6: The B\&E matrix forms the fundament for the formalisation of Chemistry according to the Dugundji/Ugi model. Accordingly a reaction of ensembles of molecules may be treated as isomerism. A molecule of $\mathrm{n}$ atoms is represented by a symmetric $\mathrm{n}$ by $\mathrm{n}$ 'BE-' matrix ('bond-electron' matrix). Diagonal entries give the number of free valence electrons, off-diagonals give the bond orders between atoms. Chemical reactions are represented by ' $\mathrm{R}$ ' matrices, which when added to the matrix representing the starting material EM matrix, generates a product matrix E giving the structure of the product.

Computer programs that emerged form the Dugundji/Ugi model are the programs RAIN and EROS, which are of considerable use in basic understanding of organic chemistry and very helpful in designing total synthesis (Figure 5). 

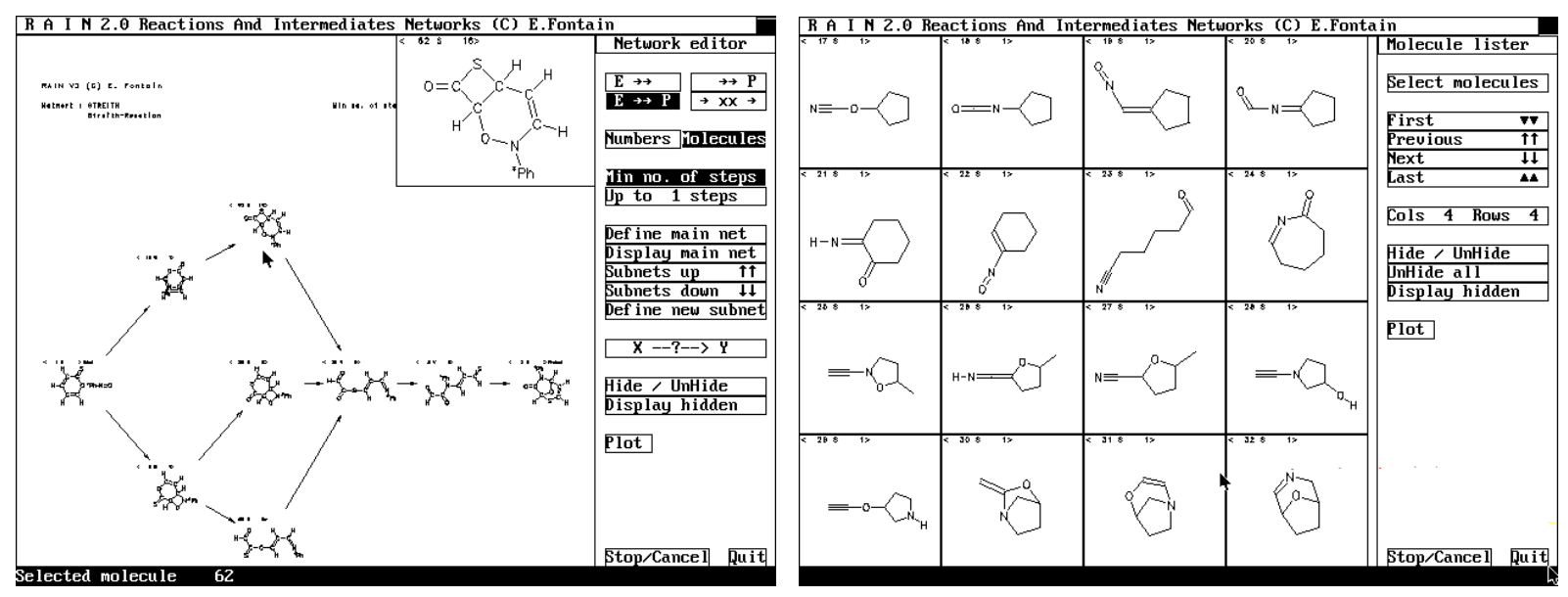

Figure 5. Screen snapshots of the computer software RAIN. (Reproduced with the kind permission of Eric Fontain).

\section{Phosphorous Chemistry}

Together with his friend the Cuban chemist Fausto Ramirez and P. Gillespie, Ivar Ugi was exploiting and developing new avenues in Phosphorous chemistry. There was a major quest for the chemoselective stepwise introduction of different substitutents onto P(IV) yielding phosphate esters and derivatives, which constitute natural products of great importance. They came up with the idea to develop cyclic P(II) and $\mathrm{P}(\mathrm{IV})$ reagents which should react highly sequentially, thus allowing the stepwise and chemoselective introduction of substitutents (Scheme 7). Many of these reagents in the following have been synthesized and optimized for the respective applications. A major application was the first synthesis of oligophosphothioates, which comprise a major class of antisense molecules.

-Novel cyclic phosphorylating agents for a sequential and selective bisphosphorylation<smiles>[Y]OC(=O)OC([Y])(O[R])O[R]</smiles>

-Novel P(III) phosphorylating agent and subsequent first report of the synthesis of oligothiophophonates<smiles>CC(C)N(C(C)C)[PH](=O)(=O)c1cccc(Cl)c1</smiles>

1. $\mathrm{N}$-methylanilinium $\mathrm{HCl}$

2. 2,3-Ac $\mathrm{C}_{2}-\mathrm{A}^{\mathrm{Tr}}$ or $2,3-\mathrm{mM}-\mathrm{m}^{7} \mathrm{G}^{\mathrm{DMTr}}$

3. ADP or ATP

4. $\mathrm{S}_{8}$

5. $\mathrm{H}_{2} \mathrm{O}$

6. $\mathrm{NH}_{3}$ or $\mathrm{H}+$

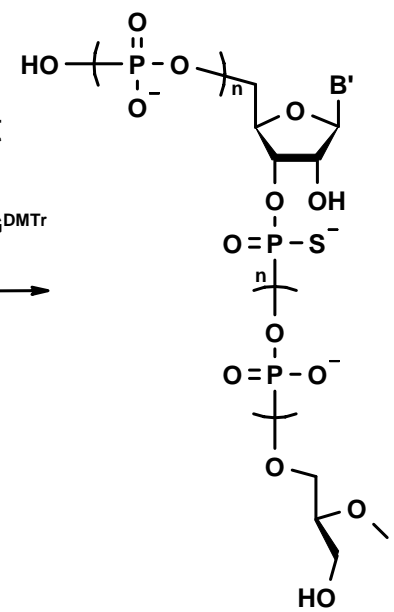


Scheme 7. Development of "programmable" cyclic phosphorylation reagents for the selective step-wise introduction of substitutents. An important application is the synthesis of oligothiophosphonates as antisense molecules.

\section{Ferrocene Chemistry}

In the context of Ugi's interest in theoretical stereochemistry and the stereoselective four component syntheses he first discovered an easy access towards chiral ferrocenylalkyl amines (Scheme 8). This reaction is another example of the power of MCR, since the product can be convergently synthesized by a $\alpha$-amino alkylation MCR of ferrocene, and aldehyde or ketone and a secondary amine. In subsequent work Ugi et al. found that the best way to run a U-4CR in a stereoselective way is to use chiral amines. A prerequisite for the chiral amine was that it should be cleavable after the performed U-4CR. Using repetitive cycles of this diastereosekective Ugi reactions and subsequent deprotection he envisioned an alternative to the peptide synthesis according to Merryfield. As a side product of his research the chiral ferrocenylalkyl amines today are important starting materials for chiral ligands used in enantioselective reactions on a technical scale.

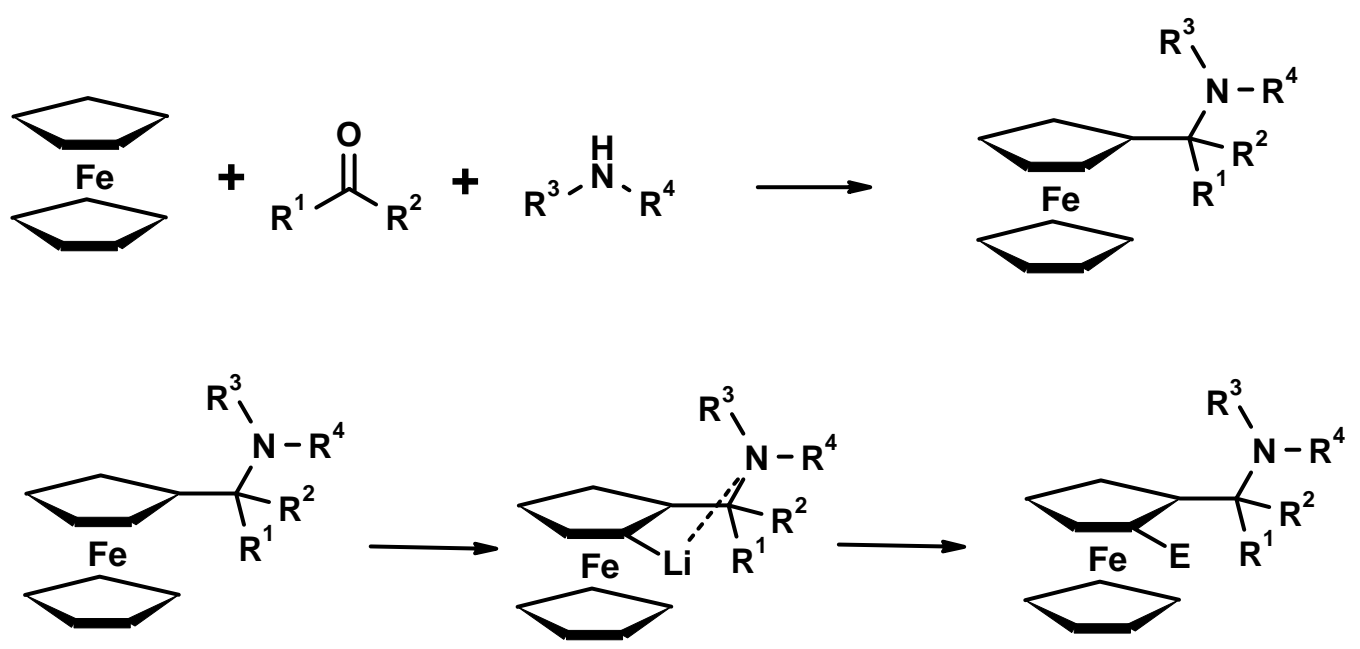

Scheme 8: First stereoselective synthesis of $\alpha$-ferrocenylalkyl amines by an $\alpha$-aminoalkylation MCR introduced by Ugi in 1972, today still the best way to access this class of important ligands useful for the preparation of chiral metal catalysts.

A late development in the academic life of Ivar was the installation of a periodically conduced conference in the growing area of multi component reaction chemistries. The first conference took place in Munich/Germany in the year $2000 .^{3}$ It was a great success, with many attending scientist from academia and industry. The next one was kindly organized by the famous and highly productive MCR group around Profs Banfi and Guanti in Genua/Italy in 2004. ${ }^{4}$

On one of these organizing meeting I had the privilege to accompany Ivar and I remember when we went to visit the local organising group in Genua to discuss the scientific program in March 2003. On a Sunday we took the opportunity to visit the nearby gorgeous landscape of Cinque Terre (Figure 6). In a small fisher village of name Lerici we had an excellent seafood launch and also tried one or two bottles of excellent local white wine. After the lunch we somehow felt very tired and Ivar proposed to have a walk to the beach. There we felt the height of our fatigue and Ivar lay on the beach and immediately drifted off. It was in early March and the spring season just started. The locals promenaded on the old stone wall leading to the harbour. Immediately they clustered around us seeing an old man snoring and sleeping on the beach. 


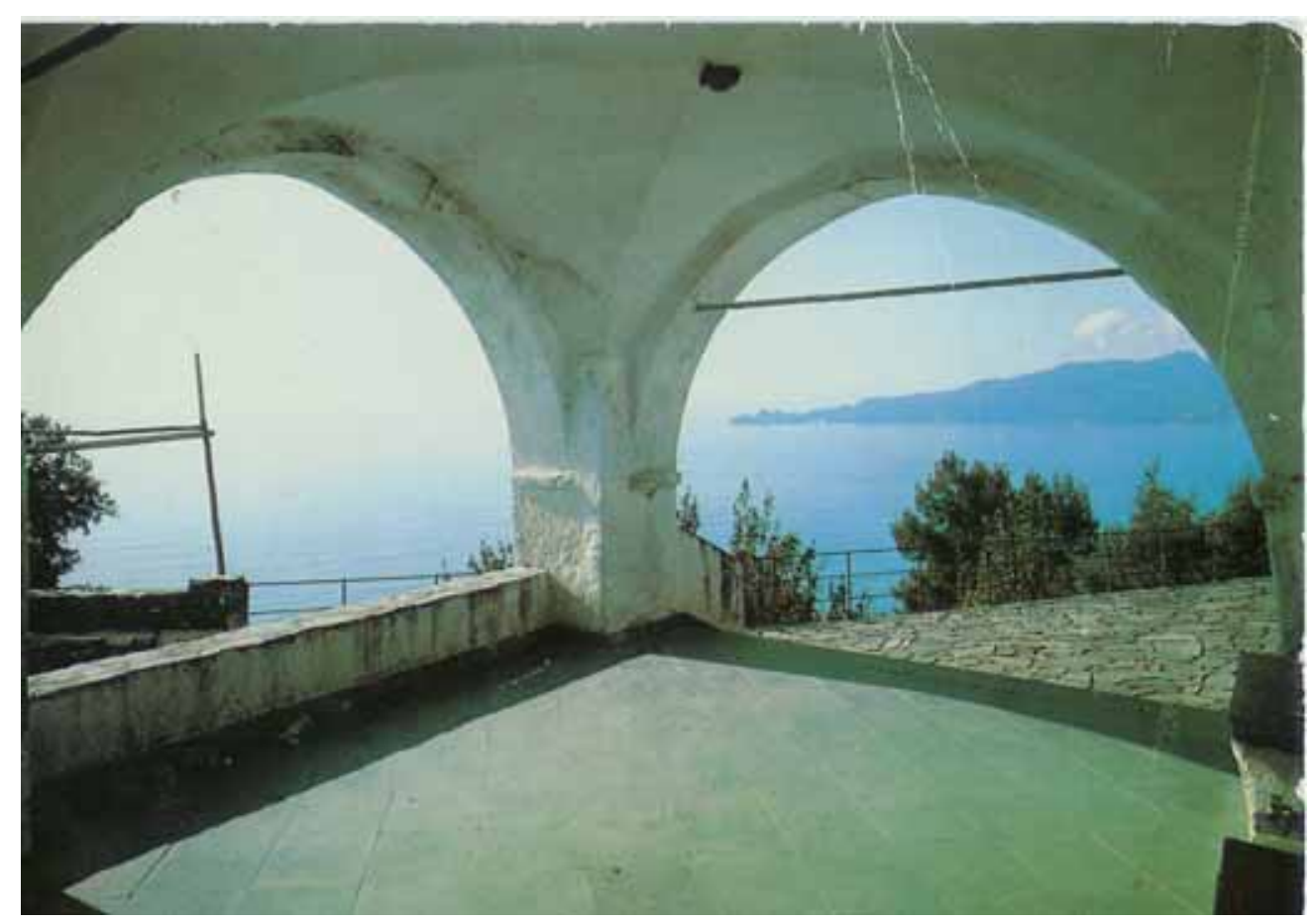

Figure 6: Santuario N.S. delle Grazie between Cinque Terre and Genua in spring 2003, Ivar Ugi preparing the MCR-2003 conference.

Continuing in the sense of Ivar Ugi the latest conference happened in Amsterdam/Netherlands and the next one is planned for 2008 happening in Ekaterinburg in Russia. ${ }^{5}$ It is hopped that the MCR conferences will establish as an ongoing regular meeting for academic and industrial scientist reflecting the growing importance of this field.

His friend and colleague Professor Sir Jack Baldwin wrote to the occasion of Ivars' death: "I was very sad to receive your email about Ivar's death. We have lost one of the most original and creative organic chemists of the last fifty years. At a time when the pressures of conformity are ever increasing, Ivar stands out as a man who was unafraid to challenge existing dogma both in the field of chemistry and also within the 'establishment'. In fact he relished this role. All those who were privileged to know him personally will remember his sense of humour and his humanity. All chemists will remember and use the marvellous Ugi Reaction.”

\footnotetext{
${ }^{1}$ J.D. Wallis, J.D. Dunitz. J. Chem. Soc., Chem. Commun. 1983, 910.

${ }^{2}$ I. Ugi ”De Jovi et de Bovi” Nachrichten aus Chemie, Technik und Labor 19.

${ }^{3}$ http://www.mcr2000.org/

${ }^{4}$ http://www.chimica.unige.it/mcr2003.htm

${ }^{5}$ http://www.hrsmc.nl/MCR2006.html
}

Dr. Alexander Doemling

Associate Professor

Pharmaceutical Sciences

University of Pittsburgh

BST3 10019, Pittsburgh, PA 15261, USA 